Role of agricultural engineering in environmental and sustainable development for

the valley and delta areas: 1938 - 1952

\title{
EFFECT OF ABSORPTION REFRIGERATION SYSTEM ON POTATO CHARACTERISTICS
}

\section{Darwesh, M.* A.H. Elmetwalli* A. Derbala,**, T. Fouda*** and M. Morad****}

\section{ABSTRACT}

The changes in potato charactristeics as a function of storage temperature and time were evaluated for different quality parameters ( physical: dimentions; chemical: reducing sugars, starch, titrable activity mechanica :weight, firmness and physiological: sprouts). under using the solar diffusion absorption refrigeration system during storage period ( two months). .The main results of this research work can be concluded and summarized as follows:-

The potato length, width, thickness, spherical shape, weight, firmness, decreasing by 5.21, 10, 11.19,12.96,9.2\% after cooling storage period respectively while infected and sorputs potato percentage and sugar concentration increased to $11.76 \%$ and $15 \%$ after cooling storage period.

\section{INTRODUCTION}

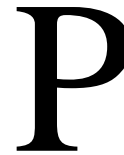

otato is considered one of the major vegetable crops that widely used as food stuff all over the world. It is usually planted three times a year. The cultivated area in Egypt is about 200000 feddans yearly producing about two millions mega gram (Mg) with an average yield of 10.3 $\mathrm{Mg}$ / feddan according to Agriculture Research Center (2004). Nourian et al. (2003) examined the potato tubers for sprouting over the entire storage period. They found that the time at which the sprouts were first noticed, generally indicating a logarithmic decrease in sprouting time as a result of higher storage temperatures. Sprouts appeared after 14, 28, 62, 112 days storage at $20^{\circ} \mathrm{C}, 16^{\circ} \mathrm{C}, 12^{\circ} \mathrm{C}, 8^{\circ} \mathrm{C}$ respectively. At $4^{\circ} \mathrm{C}$, no sprouts were observed with in the duration of the test (about 140 days) and potatoes remained healthy (no visible spoilage). Potatoes spoiled after 133, 75, 35 and 21 days of storage at $8^{\circ} \mathrm{C}, 12^{\circ} \mathrm{C}, 16^{\circ} \mathrm{C}$ and $20^{\circ} \mathrm{C}$, respectively. Chourasia et al. (2004) found that the loading density of potato in stack and cold storage $\left(534.63 \mathrm{~kg} / \mathrm{m}^{3}\right.$ and $366.01 \mathrm{~kg} / \mathrm{m}^{3}$, respectively was optimum. The percentage free space was adequate and found to be $31.54 \%$. Therefore, centre-most potatoes achieved safe temperature $\left(12-13^{\circ} \mathrm{C}\right)$ in about 10 days and the

\footnotetext{
* Lecturer, Agric. Eng. Dept., Fac. Of Agric., Tanta Univ., Egypt

** Assoc. Prof. Eng. Dept., Fac. Of Agric., Tanta Univ., Egypt

**** Prof., Agric. Eng. Dept., Fac. Of Agric., Tanta Univ., Egypt

****** Prof., Agric. Eng. Dept., Fac. Of Agric., Zagzig Univ., Egypt
} 
maximum cool-down time was about 30 days. Hence, the potatoes were safe from the rotting. Also, the temperature of potatoes at the surface was always above the critical temperature for cold injury. Chourasia et al. (2005) found that the effect of $\mathrm{RH}$ on rate of moisture loss was more pronounced at the lower range of RH (75-80\%) than at the higher range of the same (90-95\%). A 5\% increase in RH would decrease the rate of moisture loss by 0.45 and $0.437 \mathrm{~g}$ water $/ \mathrm{kg}$ of potato per day in the range of $75-80 \%$ and $90-95 \%$, respectively, at a temperature of $23.6^{\circ} \mathrm{C}$. Decrease in the storage air's $\mathrm{RH}$ from 95 to $75 \%$ would increase the moisture loss by 5.43 and 5.76 times at 23.6 and $2.1{ }^{\circ} \mathrm{C}$, respectively. Eltawil et al. (2006) stated that traditional storage practice in Egypt, the bulk of potato storage takes place in traditional structures or Nawallas made of mud bricks. Nawallas are typically privately owned and are concentrated in the northern governorates with lower average temperatures. Walls are typically from 2.5 to $3.5 \mathrm{~m}$ high and 0.3 to $0.6 \mathrm{~m}$ thick. Storage period is normally for 5 months, May to September. Saad (2006) studied the change in some physical and mechanical properties of some verities of potato during storage. This experiment excused under two storage systems (Nawalla and cold storage) temperature was 15 to $20{ }^{\circ} \mathrm{C}$ and $75 \% \mathrm{RH}$ in Nawalla and $4^{\circ} \mathrm{C}$ in vapour compression cooling. The weight losses was increased with increasing storage time and the value of losses differ with difference storage systems, in Nawalla storage system the weight losses is higher than cold storage system. Chourasia and Goswami (2007) indicated that storage loss beyond permissible limits is one of the major problems in the potato cold storage industry. The existing stack dimensions and arrangement of the stacks within the cold store is one of the reasons behind these storage losses. On the other hand, the volume and height of the stack showed just the reverse effect. The width of the stack did not make any significant change in terms of temperature of the product which increased slightly with increases in the width. Chourasia and Goswami (2008) reported that product-cooling load is one of the most important components, contributing about two-thirds toward the total refrigeration load during the transient cooling period of a cold storage. So the main objective of this research were evaluated the changes in potato quality as function of storage temperature and time. 


\section{MATERAILS AND METHODES}

Data collected during summer seasons 2008-2009 at Denosher village- El Mehalla EL Kobra-Gharbia Governorate. Potato "Spunta variety" is stored in diffusion absorption refrigeration system. A samples was taken for determining the dimensions and then the coefficient of spherical shape. Size of each potato tuber was determined by measuring the main three axis of tuber; the major axis as tuber length $(\mathrm{L})$, the intermediate diameter as tuber width (D), and the thickness of tuber (T) in millimeters using a vernier caliber with an accuracy of $0.1 \mathrm{~mm}$. The sugar concentration in tuber during potatoes storage was measured by using a refractmeter (with accuracy 0.5 Prix No.). A pentrometer used to measure a firmness of potato tubers with accuracy $1 \mathrm{~kg} / \mathrm{cm}^{2}$ and $1 \mathrm{~b} / \mathrm{in}^{2}$. The weight of each tuber was determined using an electronic digital balance having a sensitivity of $5 \mathrm{~g}$.

Table 1: The potato spunta tubers characteristics

\begin{tabular}{|l|l|l|l|}
\hline Characteristics & Spunta tuber & Characteristics & Spunta tuber \\
\hline Average weight & $130 \pm 81 \mathrm{~g}$ & Width & $47-76 \mathrm{~mm}$ \\
\hline Specific gravity & 1.0723 & Length & $77-165 \mathrm{~mm}$ \\
\hline Sugar & 15 Prix & Thickness & $35-58 \mathrm{~mm}$ \\
\hline Shape index & $2.10 \pm 0.50$ & Notes & Large tubers \\
\hline
\end{tabular}

1. Coefficient of spherical shape of the measured samples was calculated according to (Ismail, 1988) as follows:

$$
\mathrm{I}=\frac{\boldsymbol{L}}{\sqrt{\boldsymbol{D T}}} \quad \text {, decimal }
$$

Where:I $=$ Coefficient of spherical shape; $\quad \mathrm{L}=$ Length of tuber, $\mathrm{mm}$;

$$
\mathrm{D}=\text { Width of tuber, } \mathrm{mm} . \quad \mathrm{T}=\text { Thickness of potato tuber, } \mathrm{mm} \text {. }
$$

2. The theoretical volumes calculated by the following equation (Mohsenin, 1986):

$$
\mathrm{V}_{\text {theo. }}=(\pi / 6)\left(\mathrm{L}^{*} \mathrm{D} * \mathrm{~T}\right) \quad, \mathrm{mm}^{3}
$$

3. Specific gravity: Measuring specific gravity of potato tuber was used a simple technique which applies to large objects such as fruit and vegetables is the specific gravity, the potato tuber is firstly weighted on the balance scale in air and then forced into the water and attached to by third. The second reading of the balance was taken after the tuber submerged completely in water. The two readings were used in the following expression to calculate specific gravity (SG): (Mohsenin, 1986) 
$(\mathbf{S G})=$ Weight in air (g) / [Weight in air (g) - Weight in water $(\mathrm{g})](\mathbf{S G})_{\mathbf{L}}$ Where: $(\mathrm{SG})_{\mathrm{L}}$ is the specific gravity of water (equal one).

\section{Potato storage conditions.}

When entering potato crop inside refrigerator store, it should be subjected to lower temperature gradually for two weeks. After then fixed temperature between 4 to $10{ }^{\circ} \mathrm{C}$ from third week until it reach to export out storage. When extracting potato crop outside refrigerator, it should be subjected to higher temperature gradually for two to three weeks. This controlling of inside temperature refrigeration unit is required to keep potato characteristics, because potato subjected to lower or higher temperature suddenly destroyed the potato properties. Figure (1) describes the relationship between inside air temperature in refrigerator unit and outside air temperature around refrigerator unit. when entering potato crop in refrigeration unit the temperature was 14 and $12{ }^{\circ} \mathrm{C}$ during first and second week. By controlling of temperature gradually until it lowered to $4^{\circ} \mathrm{C}$ during fourth and fifth week. Before extracting potato crop, it should be increasing temperature gradually until it raised above $10^{\circ} \mathrm{C}$. The average inside temperature in refrigeration unit was $10.21^{\circ} \mathrm{C}$ when the average outside temperature and temperature difference was 29.26 and $19.05{ }^{\circ} \mathrm{C}$ during storage period ( two months). Potato storage subjected to the maximum average outside temperature was $30.7^{\circ} \mathrm{C}$ this gave a 12 and $10.5{ }^{\circ} \mathrm{C}$ of the average inside refrigeration unit. Also, the maximum average temperature difference (cooling effect) 18.7 and $20.1{ }^{\circ} \mathrm{C}$. The minimum average temperature inside refrigeration unit was $4{ }^{\circ} \mathrm{C}$ under 29.5 and $31.9{ }^{\circ} \mathrm{C}, 25.5$ and $27.9^{\circ} \mathrm{C}$ of average outside temperature and cooling effect, respectively.

\section{RESULTS AND DISCUSSION}

The potato stored characteristics in absorption refrigeration unit are affected by refrigeration conditions. The potato stored characteristics include: physical, chemical and mechanical properties; discussed as follows:

\section{Effect of cooling storage period on physical characteristics of potato} tubers

Determinations of the main dimensions of potatoes are very important for describing their technological characteristics in many respects. The measured dimensions of potato tubers include: length (L), width (W), and thickness (T) as measured for fresh potato (before storage) and stored potato (after storage). 


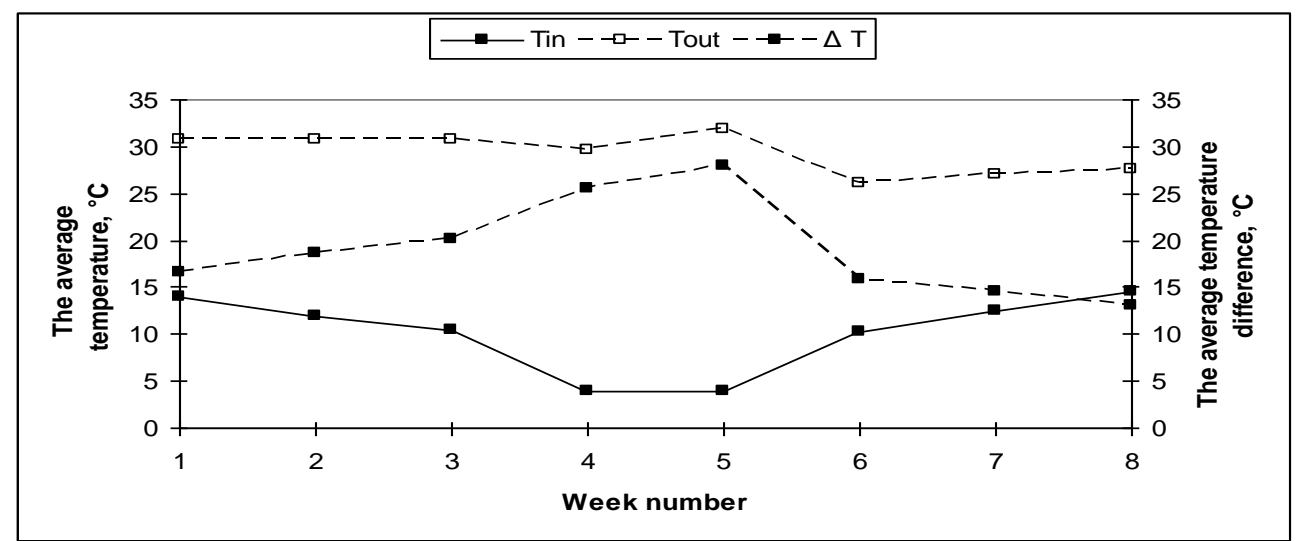

Fig. 1: The average, ambient air temperature, temperature difference and inside air temperature during storage period (two months).

Table (2): Statistical index of some physical properties for the investigated of fresh and stored potato tubers.

\begin{tabular}{|c|c|c|c|c|c|c|}
\hline Properties & Potatoes & $\begin{array}{c}\text { Average } \\
X^{-} \\
\end{array}$ & $\begin{array}{c}\text { Range } \\
\text { Max-Min }\end{array}$ & $\begin{array}{l}\text { S.D. } \\
\left(\sigma_{\mathrm{n}}-1\right)\end{array}$ & $\begin{array}{l}\text { S.E. } \\
\left.\left(S_{X}\right)^{-}\right)\end{array}$ & $\begin{array}{c}\text { C.V. } \\
\%\end{array}$ \\
\hline Tube & Fresh & 114 & $165-77$ & 22.37 & 3.72 & 19.62 \\
\hline Length & Stored & 107.85 & 152 & 21.69 & 3.61 & 20.11 \\
\hline Tuber & Fresh & 60.08 & $76-47$ & 7.53 & 1.25 & 12.25 \\
\hline Width, m & Stored & 54.08 & $70-40$ & 7.80 & 1.30 & 14.40 \\
\hline Tuber & Fresh & 46.58 & 58-35 & 5.30 & 0.88 & 11.39 \\
\hline Thickness, mm & Stored & 41.29 & $53-33$ & 5.33 & 0.88 & 12.83 \\
\hline Coefficient of & $\mathrm{Fr}$ & 2.17 & $3.77-1.5$ & 0.46 & 0.07 & 21.1 \\
\hline $\begin{array}{c}\text { Spherical } \\
\text { shape }\end{array}$ & Stored & $\begin{array}{l}2.17 \\
1.89\end{array}$ & $2.68-1.35$ & $\begin{array}{l}0.40 \\
0.37\end{array}$ & $\begin{array}{l}0.07 \\
0.06\end{array}$ & $\begin{array}{l}21.1 \\
19.57\end{array}$ \\
\hline Potato tuber & & 239.35 & 42 & 83.61 & 13.93 & 34.93 \\
\hline Weigh & Stored & 224.26 & $390-85$ & 77.77 & 12.96 & 34.67 \\
\hline & & 170.21 & 292.09-68. & 55.12 & 9.18 & 32.38 \\
\hline volume, $\mathrm{cm}^{3}$ & Stored & 130.21 & $229.14-47.68$ & 49.48 & 8.24 & 38 \\
\hline
\end{tabular}

Typical mean values, obtained from large number of observations for the investigated potato before and after storage, are given in Table (2), with the arithmetic means of all samples, range of values, and other statistical indices for the main dimensions of the studied varieties, such as standard deviation $\left(\sigma_{\mathrm{n}}-1\right)$, standard error (S.E), and coefficient of variance (C.V., \%) to show the dispersion of the measured values around the mean.

For the sake of clarity, the results of physical properties of the two different investigated conditions of potato tubers which were measured or calculated, 
statistically analyzed, represented graphically either in a variation frequency distribution curves or plotted in a histogram of the mean values, are discussed as follows:

\section{Frequency distribution of dimensions of potato tubers:}

\section{a- Potato tuber length:}

Figure (2a) indicates the frequency distribution curve and mean values for fresh and stored tubers length. The figure shows that the frequency distribution for the length of fresh potato was $0 \%$ of tubers< $65 \mathrm{~mm}, 2.94 \%$ of tubers ranged from 65 to $75 \mathrm{~mm}, 11.76 \%$ of tubers ranged from 75 to $85 \mathrm{~mm}, 26.47 \%$ of tubers ranged from 85 to $95 \mathrm{~mm}, 20.38 \%$ of tubers ranged from 95 to $105 \mathrm{~mm}, 2.94 \%$ of tubers ranged from 105 to $115 \mathrm{~mm}, 8.82 \%$ of tubers ranged from 115 to $125 \mathrm{~mm}, 17.64 \%$ ranged from 125 to $135 \mathrm{~mm}$, $2.94 \%$ of tubers ranged from 135 to $165 \mathrm{~mm}$. The corresponded frequency distribution for the length of stored potato was $2.94 \%$ of tubers $<75 \mathrm{~mm}$, $11.76 \%$ of tubers ranged from 75 to $85 \mathrm{~mm}, 20.58 \%$ of tubers ranged from 85 to $95 \mathrm{~mm}, 20.58 \%$ of tubers ranged from 95 to $105 \mathrm{~mm}, 11.76 \%$ of tubers ranged from 105 to $115 \mathrm{~mm}, 2.94 \%$ of tubers ranged from 115 to $125 \mathrm{~mm}$, $14.70 \%$ of tubers ranged from 125 to $135 \mathrm{~mm}, 11.76 \%$ of tubers ranged from 135 to $145 \mathrm{~mm}, 2.94 \%$ of tubers ranged from 145 to $155 \mathrm{~mm}$ and $0 \%$ of tubers $<165 \mathrm{~mm}$. Linear regression analysis was applied to the data of potato tubers length after and before storage in absorption refrigerator unit (Figure 3a). The equation with the best fit was as follow:

$$
\mathrm{Y}=\mathrm{bX}
$$

Where: $\mathrm{Y}$ is length after storage, $\mathrm{mm}$

$\mathrm{X}$ is length before storage, $\mathrm{mm}$; and

$\mathrm{b}$ is the slope of straight line

The slope of straight line was as follows:

$\mathrm{L}_{\text {before storage }}=0.9638 \mathrm{~L}_{\text {before storage }}, \mathrm{R}^{2}=0.9764$

\section{b- Potato tubers width:}

Figure (2b) indicates the frequency distribution curve and mean values of fresh potato tubers width (fresh and stored). The figure show that the frequency distribution for the width of fresh potato tubers was $0 \%<45 \mathrm{~mm}$, $5.80 \%$ of tubers ranged from 45 to $50 \mathrm{~mm}, 17.64 \%$ of tubers ranged from 50 to $55 \mathrm{~mm}, 26.47 \%$ of tubers ranged from 55 to $60 \mathrm{~mm}, 23.52 \%$ of tubers ranged from 60 to $65 \mathrm{~mm}, 11.76 \%$ of tubers ranged from 65 to $75 \mathrm{~mm}$ and $2.94 \%$ of tubers $<80 \mathrm{~mm}$. 


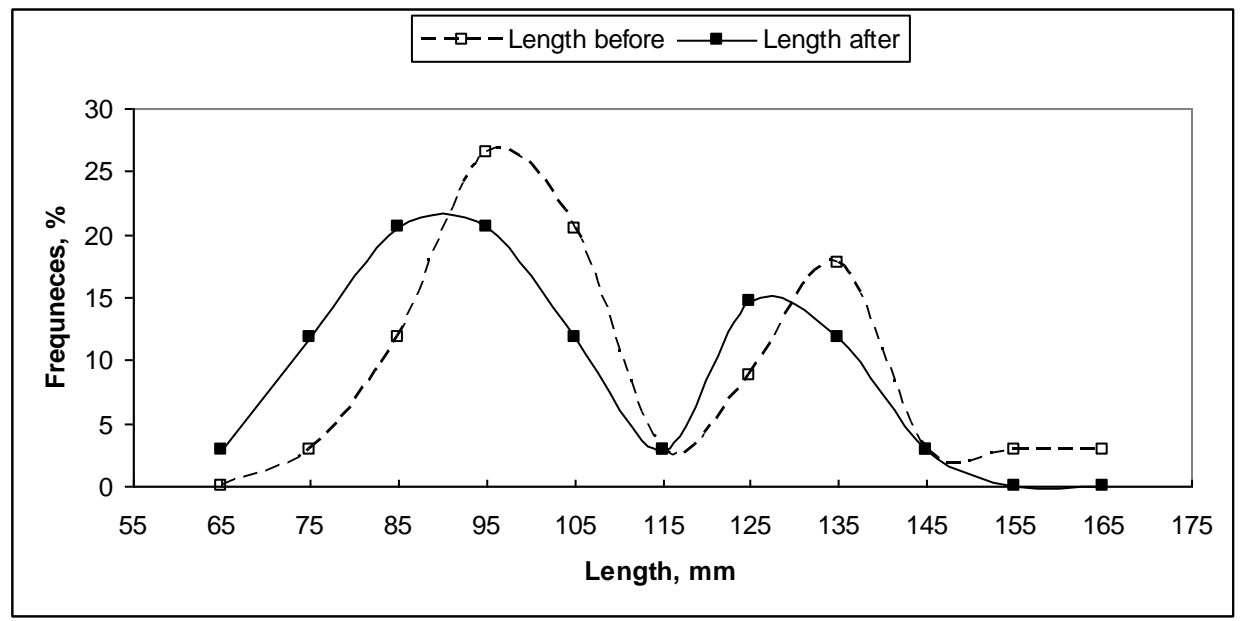

a- Frequency of length

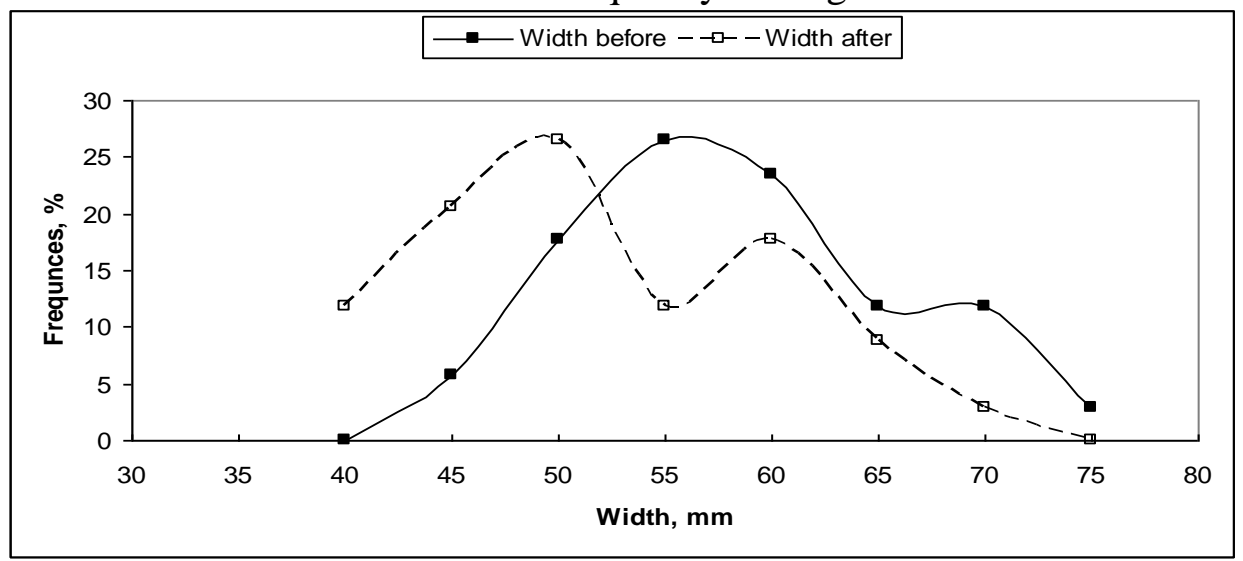

b- Frequency of width

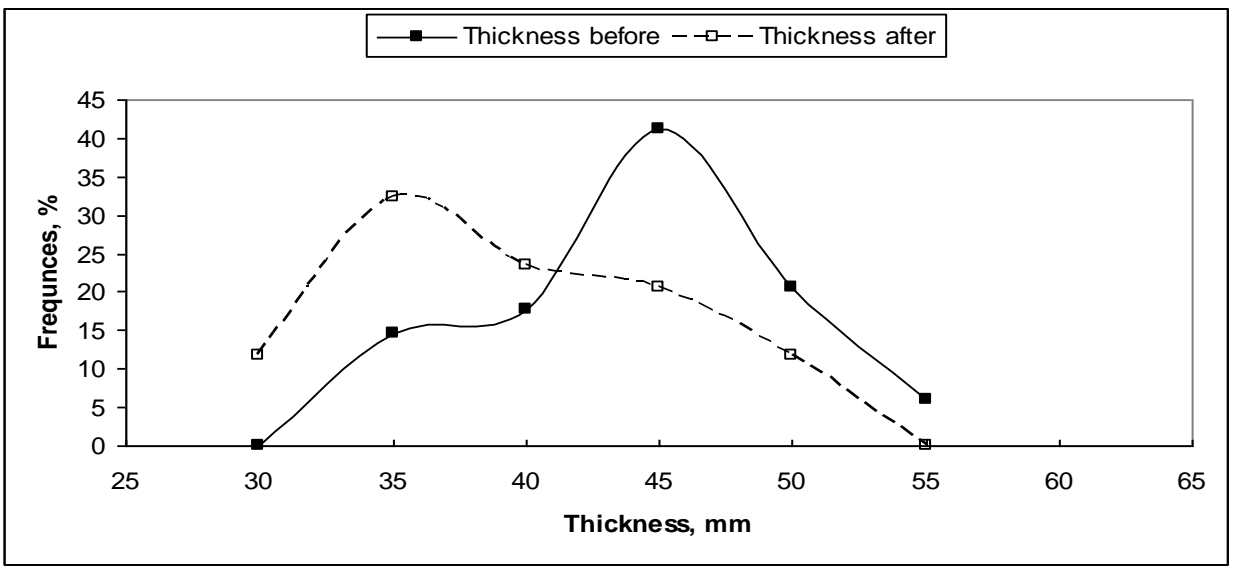

c- Frequency of thickness

Fig. : 2. $(a, b, c)$ : Frequency distribution curves of dimensions for the investigated fresh and stored potato tubers. 


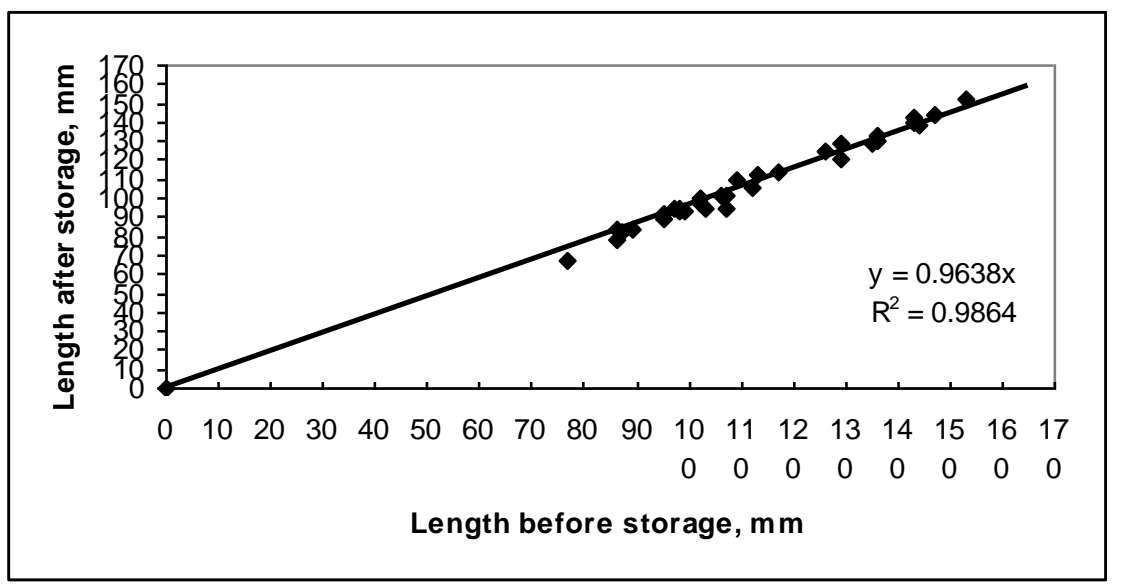

a. Linear regression of length

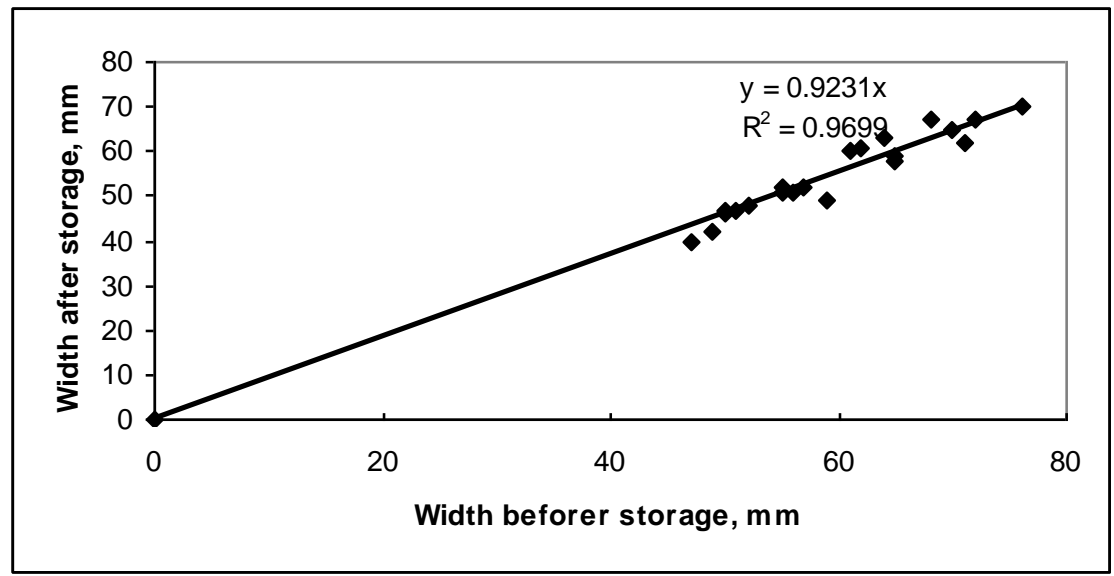

b. Linear regression of width

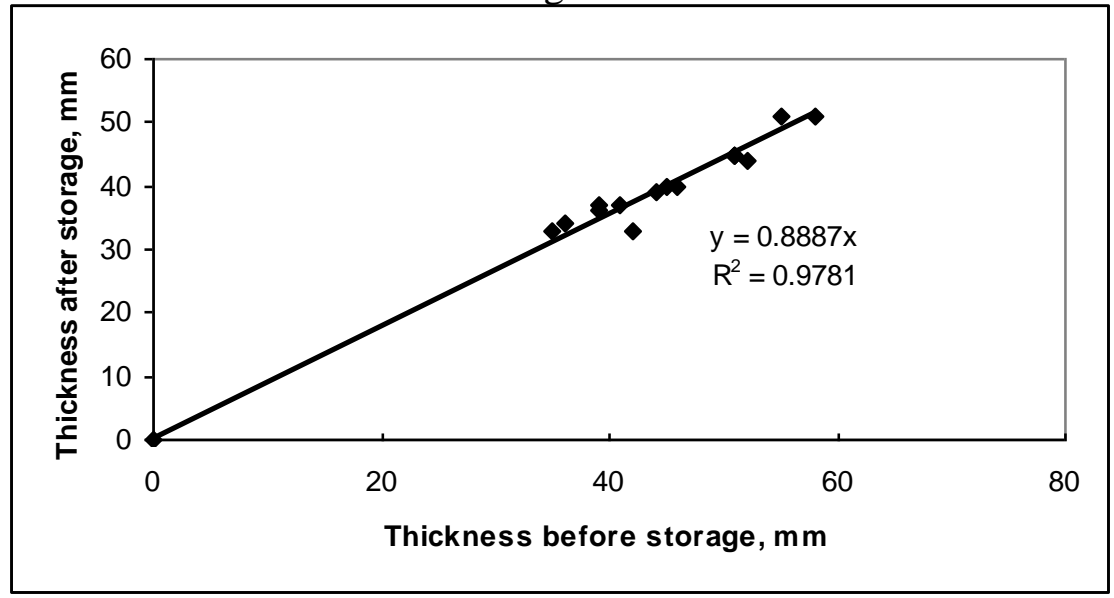

c. Linear regression of thickness

Fig. 3: (, a, b, c): Linear regression of dimensions before and after storage. 
The corresponding frequency distribution for fresh potato tubers width of stored potato tubers was $11.76 \%<45 \mathrm{~mm}, 20.58 \%$ of tubers ranged from 45 to $50 \mathrm{~mm}, 26.47 \%$ of tubers ranged from 50 to $55 \mathrm{~mm}, 11.76 \%$ of tubers ranged from 55 to $60 \mathrm{~mm}, 17.64 \%$ of tubers ranged from 60 to $65 \mathrm{~mm}, 8.82 \%$ of tubers ranged from 65 to $70 \mathrm{~mm}, 2.94 \%$ of tubers ranged from 70 to $75 \mathrm{~mm}$ and $0 \%$ of tubers $<80 \mathrm{~mm}$.

Linear regression analysis was applied to the data of fresh and stored of potato tubers width in absorption refrigeration unit (Figure 3b). The equation with the best fit was as follow:

$\mathrm{W}_{\text {before after }}=0.9231 \mathrm{~W}_{\text {before storage }}, \mathrm{R}^{2}=0.9135$

\section{c-Potato tubers thickness}

Distribution for the thickness of fresh was $0 \%$ of tubers $<35 \mathrm{~mm}, 14.70 \%$ of tubers ranged from 35 to $40 \mathrm{~mm}, 17.64 \%$ of tubers ranged from 40 to $45 \mathrm{~mm}$, $41.17 \%$ of tubers ranged from 45 to $50 \mathrm{~mm}, 20.58 \%$ of tubers ranged from 50 to $55 \mathrm{~mm}$ and $5.88 \%$ of tubers $\leq 55 \mathrm{~mm}$. The corresponded frequency distribution for the thickness Linear regression of length of stored was $11.76 \%$ of tubers $<35 \mathrm{~mm}, 32.35 \%$ of tubers ranged from 35 to $40 \mathrm{~mm}$, $23.52 \%$ of tubers ranged from 40 to $45 \mathrm{~mm}, 20.58 \%$ of tubers ranged from 45 to $50 \mathrm{~mm}, 11.76 \%$ of tubers ranged from 50 to $55 \mathrm{~mm}$ and $0 \%$ of tubers $<55 \mathrm{~mm}$. Linear regression analysis was applied to the data of fresh and stored of potato tubers thickness in absorption refrigerator unit (Figure 3c). The equation with the best fit was as follow:

$\mathrm{T}_{\text {after storage }}=0.8887_{\text {before storage, }} \mathrm{R}^{2}=0.9097$

\section{d- Coefficient of spherical shape:}

The results in Figure (4) shows that fresh and stored potato tubers plotted through the coefficient from 1.4 to 3 . Most fresh and stored potato tubers take oval shapes which have a coefficient of spherecity $>1.5$. Meanwhile $2.94 \%$ and $20.58 \%$ of fresh and stored potato tubers take a spherical shape, which have a coefficient of spherical shape $\leq 1.5$. The obtained values of C.V., \% for potato coefficient of spherical shape were (21.10 and 19.57\%) for fresh and stored potato tubers, respectively.

\section{Weight of potato tuber}

Fresh and stored potato tubers weight was measured, statistically analyzed, and results of frequency distribution are shown in Figure (5). The figure 
shows that the frequency distribution for the mass of fresh potato was $2.94 \%$ of tubers $<100 \mathrm{~g}, 5.88 \%$ of the tubers ranged from 100 to $150 \mathrm{~g}, 29.41 \%$ of

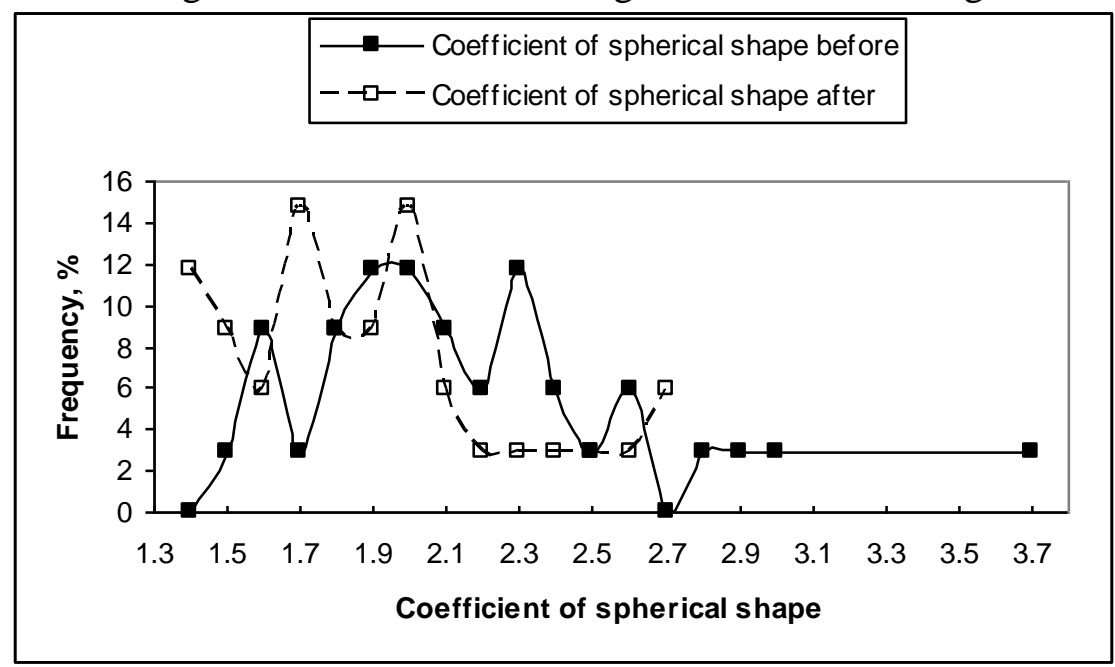

Fig 4: Frequency distribution curves of coefficient of spherical shape for the investigated fresh and stored potato.

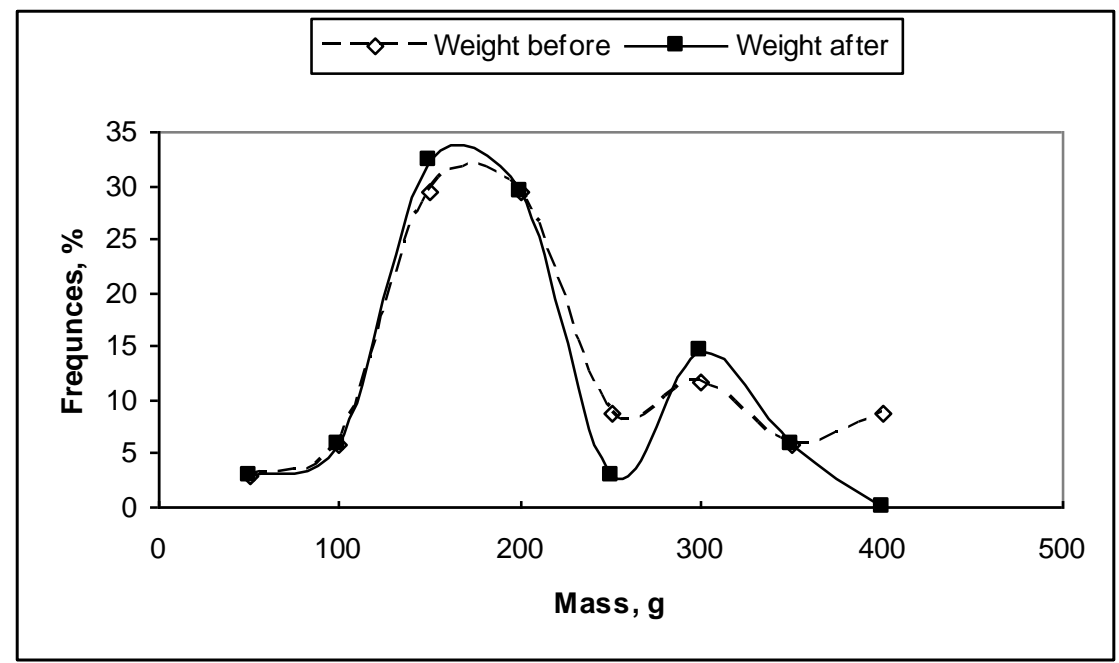

Fig. 5: Frequency distribution curves of weight for the investigated fresh and stored potato tubers.

the tubers ranged from 150 to $250 \mathrm{~g}, 8.79 \%$ of the tubers ranged from 250 to $300 \mathrm{~g}, 11.76 \%$ of the tubers ranged from 300 to $350 \mathrm{~g}, 5.88 \%$ of the tubers ranged from 350 to $400 \mathrm{~g}$ and $8.82 \%$ of the tubers $<450 \mathrm{~g}$.

The corresponding frequency distribution for the mass of stored potato was $2.94 \%<100 \mathrm{~g}, 5.88 \%$ of the tubers ranged from 100 to $150 \mathrm{~g}, 32.35 \%$ of the 
tubers ranged from 150 to $200 \mathrm{~g}, 29.41 \%$ of the tubers ranging from 200 to $250 \mathrm{~g}, 2.94 \%$ of the tubers ranged from 250 to $300 \mathrm{~g}, 14.70 \%$ of the tubers ranged from 300 to $350 \mathrm{~g}, 5.88 \%$ of the tubers ranged from 350 to $400 \mathrm{~g}$ and $0 \%$ of the tubers $<450 \mathrm{~g}$.

The statistical analysis showed that the C. V. was 34.93 and $34.67 \%$ for fresh and stored potato, respectively. Multiple regression equations were determined to describe the relationship between potato mass and its main dimensions for the fresh and stored potato tubers (Figure 6). The equations with the best fit as follows:

Fresh potato $\mathrm{W}=3.37 \mathrm{~L}+0.53 \mathrm{~W}+6.17 \mathrm{~T}, \quad \mathrm{R}^{2}=0.926$

Stored potato $\mathrm{W}=2.49 \mathrm{~L}+2.73 \mathrm{~W}+2.54 \mathrm{~T}, \quad \mathrm{R}^{2}=0.923$

It could be concluded that the dimensions $(\mathrm{mm})$ of the fresh and stored potato tubers were directly proportional with its weight for both fresh and stored tubers.

\section{Specific gravity of potato tuber}

Specific gravity is the one of the physical properties. Specific gravity was investigated fresh and stored potato. The obtained mean values of fresh and stored potato tubers were (1.047 and 1.028), respectively. The maximum value of specific gravity was 1.088 and 1.062 for fresh and stored potato tubers, respectively. The minimum value of specific gravity was 1.012 and 0.998 for fresh and stored potato tubers, respectively. The previous result indicated that the specific weight for potato stored was less than fresh potato.

\section{Mechanical characteristics of potato tubers}

The obtained mean firmness of fresh and stored potato tubers were 0.64 and 0.56 , respectively. The maximum and minimum fresh and stored potato firmness were ( 0.6 to 0.7$)$ and ( 0.3 to 0.7$)$, respectively. This means that the firmness of potato stored is less than fresh potato.

\section{Chemical characteristics of potato tubers}

The results of the sugar concentration (S.C, Prix) ranged from 5 to 6 Prix before storage . Meanwhile, This values ranged from 6.5 to 7 Prix

\section{Storage losses}

The storage evaluation depends upon the change of potato tubers characteristics after storage and the number of potatoes lost by infection and sprouts. The change of dimensions after storage process as a reduction was $5.21,10,11.19$, and $12.76 \%$ for length, width, thickness and coefficient of spherical shape, respectively. Also, the reduction rate of weight was $9.2 \%$ 
after storage process. The potato subjected to infection was $5.88 \%$ of stored potato tubers. The potato tubers which had sprouts were $11.76 \%$. The number of sprouts ranged from 6 to 8 in absorption refrigerator unit. The best potato tuber was $82.35 \%$ of potato tubers. after storage. This means that the sugar concentration of stored potato is higher than the fresh potato.

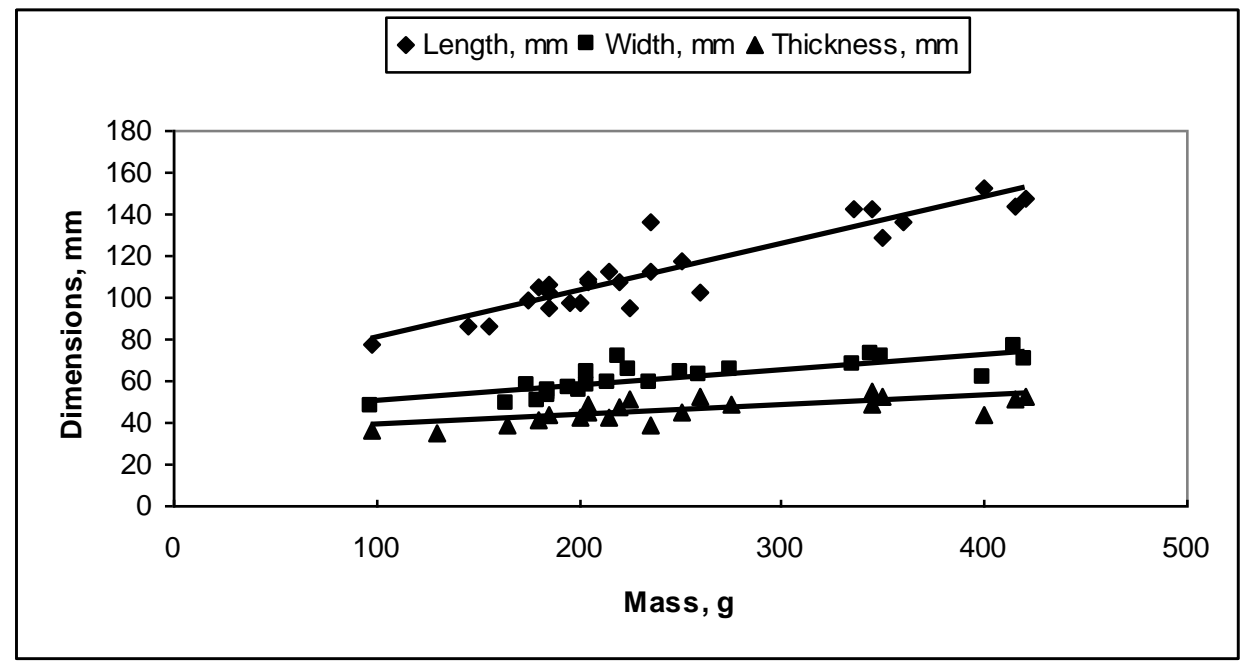

a. Fresh potato

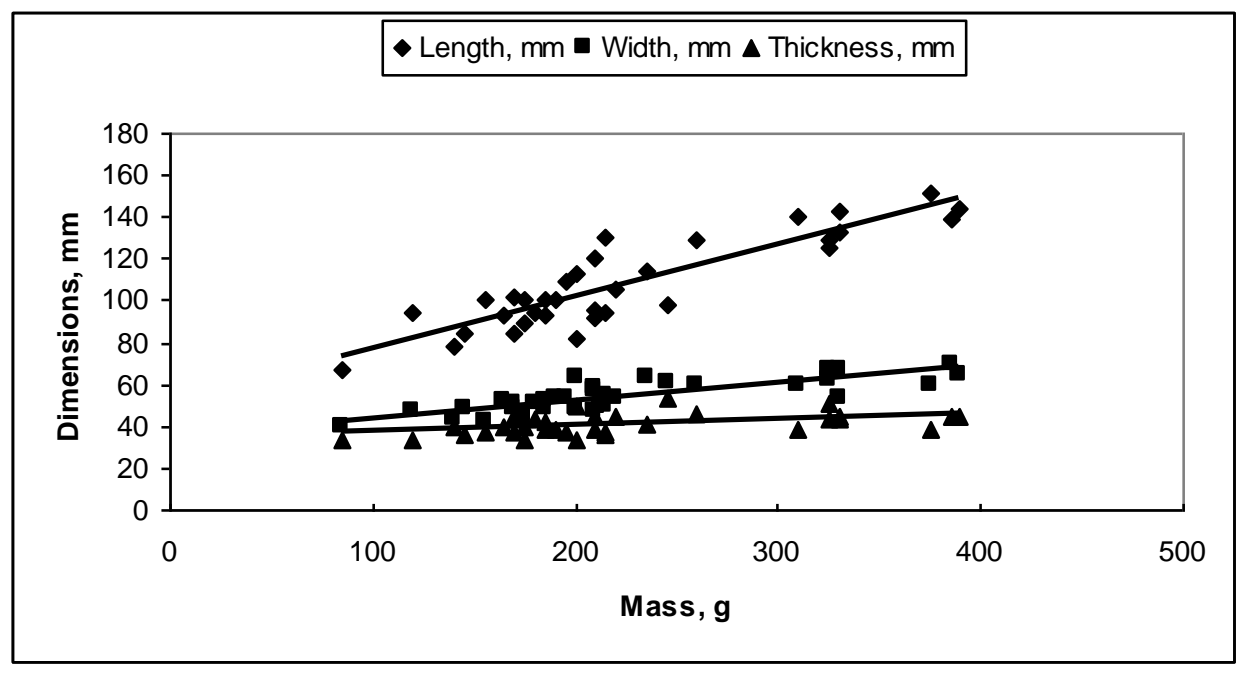

b. Stored potato

Fig. 6: Relationship between weight and dimensions for fresh and stored potato tubers. 


\section{CONCLUSION}

The mean values of potato length varied (from 77 to $165 \mathrm{~mm}$ ) before storage, While it ranged (from 67 to $152 \mathrm{~mm}$ ) after storage . And decreasing rate of length was $5.21 \%$. The mean values of potato width varied (from 47 to 76 $\mathrm{mm}$ ) before storage, while it ranged (from 40 to $70 \mathrm{~mm}$ ) after storage and decreasing rate of width was $10 \%$.

The mean values of potato thickness varied(from 35 to $58 \mathrm{~mm}$ ) before storage, while it ranged (from 33 to $53 \mathrm{~mm}$ ) after storage and decreasing rate of thickness was $11.19 \%$.

The coefficient of spherical shape of potato varied (from 1.53 to 3.77) before storage, while it ranged (from 1.35 to 2.68 ) after storage.

The mean values of potato weight varied (from 98 to $420 \mathrm{~g}$ ) before storage, while it ranged (from 85 to $390 \mathrm{~g}$ ) after storage.

The mean values of firmness of potato tuber ranged from $\left(0.6\right.$ to $\left.0.7 \mathrm{~N} / \mathrm{mm}^{2}\right)$ before storage and it ranged (from 0.3 to $0.7 \mathrm{~N} / \mathrm{mm}^{2}$ ) after storage.

The mean values of sugar concentration of potato tube range (from 15 to 16.04, Prix) and it varied( from 16.5 to 17.5 Prix ).

The infected potato was $5.88 \%$, the potato which had a sprouts was $11.76 \%$ and the potato good healthy was $82.35 \%$.

\section{REFERANCES}

Agricultural Research Center (2004). Potato cultivation and production in Egypt. Ministry of Agric., Agric. Research Center, scientific report No. 813.

Chourasia, M. K. and T. K. Goswami (2007). Simulation of effect of stack dimensions and stacking arrangement on cool-down characteristics of potato in a cold store by computional fluid dynamics. Biosystems Engineering, 96: 503-515.

Chourasia, M. K. and T. K. Goswami (2008). Product-cooling load and moisture loss under different loading patterns and cooling rates of potatoes in cold storage. Journal of Food Process Engineering, 31:339353.

\section{Chourasia, M. K.; P. Maji.; A. Baskey and T. K. Goswami (2005).}

Estimation of moisture loss from the cooling data of potatoes. Journal of Food Process Engineering, 28: 379-416. 
Chourasia, M.K .; R. Saha.; A. De; P. K. Sahoo (2004). Evaluation storage losses in a commercial potato cold storage. Journal of Food Sciences and Technology, 41:507-510.

Eltawil, M. A.; D. V. K. Samuel and O. P. Singhal (2006). Potato storage technology and store design aspects. Agricultural Engineering International: the CIGR Ejournal. Invited Overview No. 11. Vol. VIII.

Ismail, Z. E. (1988). Potao crop - Agriculture - Harvesting - Handling Storage. El-Mareff structure in Alexandria, : 23-57

Mohsenin, N. N. (1986). Physical properties of plant and animal materials. Gordon of Breach science publisher, New York.

Nourian, F.; H. S. Ramaswamy and A. C. Kushalappa (2003). Kinetics of quality change associated with potatoes stored at different temperatures. Lebensm-wiss. U-Tecnol, 36: 49-65.

Saad, A.M. (2006). A study of some engineering factors affecting potatoes handlingand storage efficiency. M. Sc. Dep. Of Agric. Eng., Faculty of agriculture. Menofiya University, Egypt.

\section{الملخص العربي \\ تأثير التيريد بالامتصاص على مواصفات البطاطس}

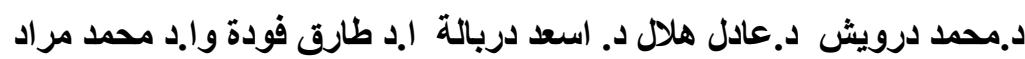

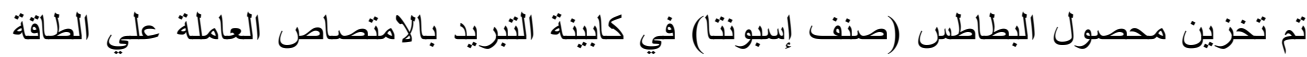

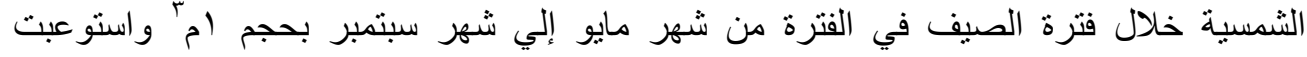

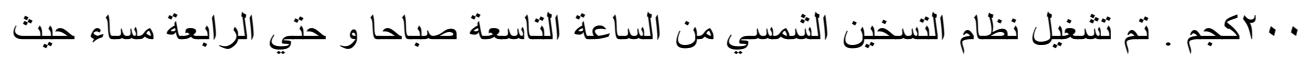

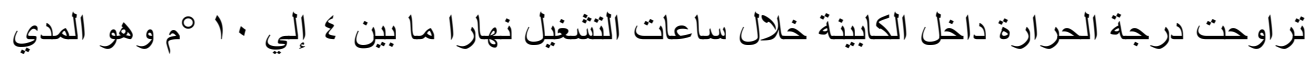

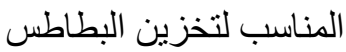

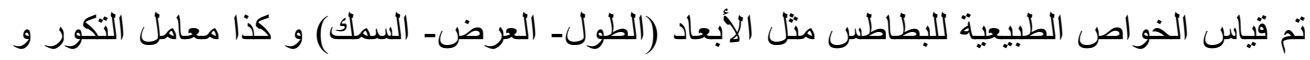

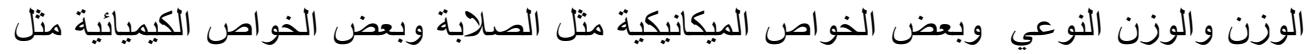

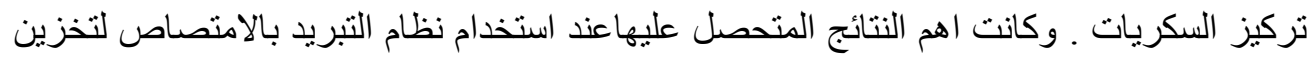

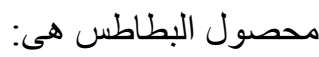

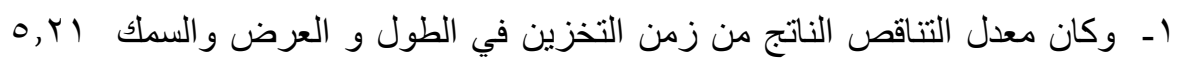

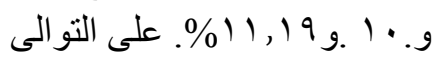

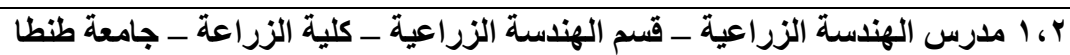

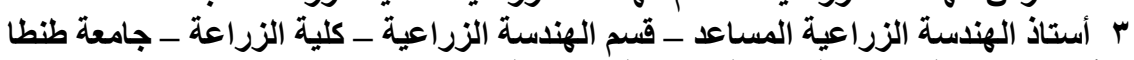

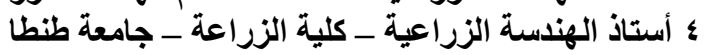

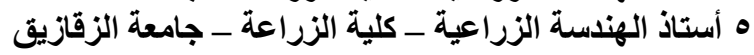




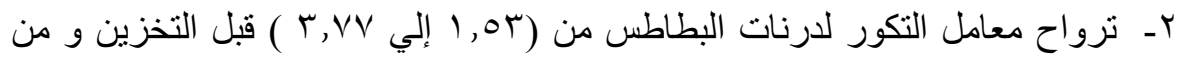

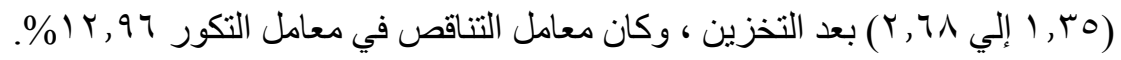

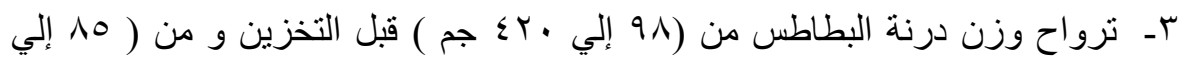

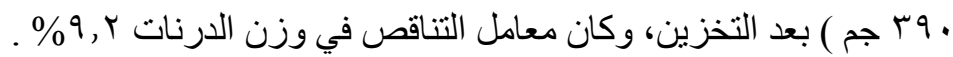

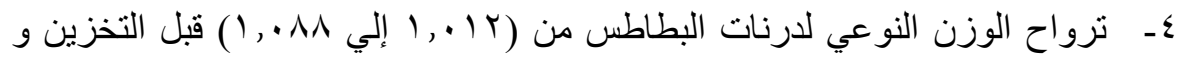

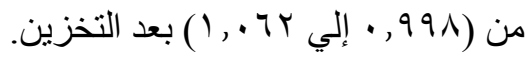

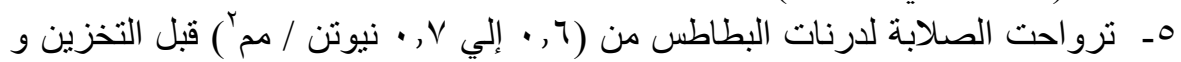

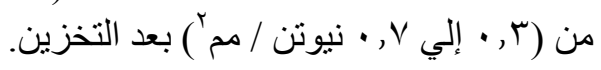

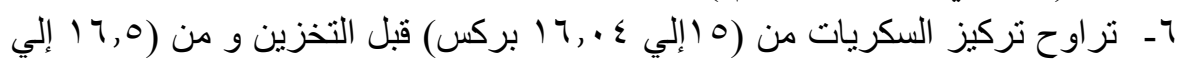

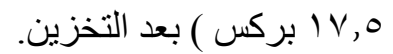

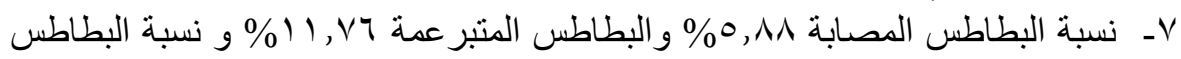

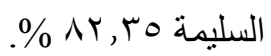

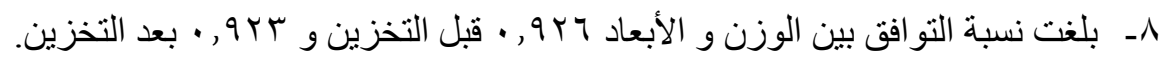

